\title{
The Effects of CEO Tenure on Earnings Management: The Role of CEO Career Origin and Affiliated Relationships
}

\author{
Massaid Bimo Setyawan ${ }^{1}$, Viska Anggraita ${ }^{1 *}$ \\ ${ }^{1}$ Faculty of Economics and Business, Universitas Indonesia, Depok 16424, Indonesia \\ ${ }^{*}$ Corresponding Author: viska257@gmail.com
}

\begin{abstract}
Consensus about ownership concentration in Indonesian firms suggests that the agency problem in Indonesia is expected to be different from other countries. This study aims to review the impact of CEO career concerns on earnings management. The study uses the regression method with samples of CEOs of companies listed on the Indonesia Stock Exchange from 2012 to 2014. Newly appointed CEOs have been proved to use real and accruals earnings management to increase profits in the early period of their tenures, while CEOs leaving their posts use only real earning management to increasing earnings in the final year of their tenure. CEO career origin and shareholder affiliation have not been proved to effect newly appointed CEO's earnings-management activities. The study concludes there is a preference for CEOs to use real earnings management during their tenures and so the enforcement of regulations related to the disclosure of management career profiles is encouraged.
\end{abstract}

Keywords: Earning Management; CEO Tenure; CEO Career Origin; CEO Affiliation; CEO Career Concerns.

\section{INTRODUCTION}

A Chief Executive Officer (CEO) is the individual considered most responsible and accountable for the policies pursued by a firm ${ }^{1}$. Shareholders and managerial labor markets keep a careful eye on firm performance to direct their revisions of expectations of $\mathrm{CEOs}^{2}$. The consideration by a CEO of current firm performance because it influences incentives he/she will receive in the future is termed "career concerns"

The purpose of this study is to investigate the effects of a CEO's career concerns on the earnings-management practices of a firm. Career concerns are measured by observing two primary periods during a CEO's tenure, namely the early and final years ${ }^{4}$. In an attempt to analyze earnings-management practices during the early years of a CEO's service, this study also uses CEO's career origin and affiliate relationships as moderating variables. To assess firm earnings quality, accrual-based and real earnings-management practices are used as a proxy ${ }^{5}$. Accounting measures of earnings, including earnings quality, are tools or aids to help investors perform evaluations of firm's performance, including the CEO's performance.

Using a sample of CEOs of firms listed in the Indonesia Stock Exchange for the period of 2012-2014, we find that Indonesian CEOs have an average of 6.15 years of tenure, with $65 \%$ of them being internally recruited CEOs, $51 \%$ of whom have an affiliate relationship with shareholders. Firms with controlling family ownership have CEOs with a tenure 2.8 years longer than CEOs in non-family-controlled ownership. Studies give evidence that in the early years of service, CEOs perform accrual-based and real earnings-management practices, while only real earnings management is used by CEOs in their final years of service. No studies have found evidence of moderating effects of career origin and affiliate relationship on the practice of earnings management.

This research aims to contribute to accounting science as follows: first, it develops previous research ${ }^{5,6}$. In addition to combining the approaches from these two studies, it also takes ownership concentration and the CEO succession process into consideration, by introducing the variable of an affiliate relationship between CEOs and shareholders. Second, this study strives to present a deeper insight into first-type agency practices in Indonesia, particularly in regard to Indonesian CEOs. Recent studies of CEOs and earnings management in the Indonesian context have been focused on the CEO succession process ${ }^{7-9}$. In contrast to these studies, this research considers a longer time period over which to observe more thoroughly and holistically the effects of CEOs' career concerns on the earnings-management practices of firms. Last, this is the first study which measures CEOs' career concerns in Indonesia in terms of their length of tenure. This study is expected to be able to provide a description of the relevance of the said concept to the Indonesian context. 


\section{LITERATURE REVIEW AND HYPOTHESIS DEVELOPMENT}

The consideration of career concerns is a theoretical approach implemented by prior studies to examine a CEO's incentives in carrying out earnings management. Career concerns can be defined as concerns by managers about their current performance because such performance can influence incentives they will receive in the future ${ }^{3}$.

Managers will put a great deal of effort into maximizing a firm's ongoing performance because it is consistent with their interests in the managerial labor market ${ }^{2}$. However, competition in the market is not yet effective and exists only when shareholders are unaware of the firm's capabilities ${ }^{10}$. In order to control management performance, a contract based on a managerial performance evaluation is required, which includes implicit incentives (for example, post-retirement promotion, or appointments) and explicit incentives (for example, salaries, bonuses, or percentages) ${ }^{3}$. During their careers, managers exhibit changes in their preferences for the types of incentives they receive ${ }^{11}$ which have effects on their career concern motivations.

Previous studies have established an understanding of CEO influence on a wide variety of financial variables, one of which is accounting policy choice, although these have not gained popularity in Indonesia yet. A CEO is a representative of managers in agency issues, and previous studies have focused on various decision-making processes related to monetary policies and firm operations as reflected by CEO characteristics. Studies of earnings management and CEOs' focus on CEO compensation ${ }^{11,12}$, CEO ownership ${ }^{13-14}$, CEO age ${ }^{15}$, CEO succession process $^{16,17}$, CEO tenure ${ }^{4,18}$, CEO career origin ${ }^{6}$; and CEO family relationships with the firm ${ }^{19}$. This study will fill research gaps by investigating the effects of CEO tenure and career origin on earnings-management practices, as well as introducing the existence of an affiliate relationship as a relevant variable in the Indonesian context, in which ownership concentration is commonly found.

\section{Earnings-Management Practices by Newly Appointed CEOs in Their Early Years of Service}

Previous research identified new CEOs' motivation to signal their abilities to shareholders in their early years of service $^{4}$. First, it is suggested that in the early years, shareholders are assessing the new CEOs' ability to manage firm resources and that this may influence or determine whether new CEOs retain their positions and stay in office. Such decisions reflect the complexity of a CEO's functions and the various firm-specific factors that not all managers can possess. Second, by showing that they have the required ability, it is expected that shareholders will provide CEOs with the flexibility to manage firm resources and so reduce excessive monitoring of their performance in the future. Third, a higher level of ability affects a CEO's potential for higher long-term compensation.

CEOs pay attention to the firm's reported earnings because it is an effective means of signaling which they can use to influence owners. In their early years of their service, CEOs can carry out opportunistic income-increasing earnings management to reinforce positive signals to shareholders and labor markets about their ability ${ }^{4}$. Because of the high incentives new CEOs receive from managerial labor markets and shareholders in their early years of service, in response to their demonstrated abilities, new CEOs try opportunistically to overstate the firm's reported earnings, according to market and shareholder expectations, and thus a hypothesis can be formulated as follows: H1: In the early years of his/her service, a CEO carries out income-increasing earnings management.

\section{Earnings-Management Practices by CEOs in Their Final Years of Service}

The majority of incentives CEOs seek to maximize in their early years of service are implicit incentives, reflecting the length of the time horizon of their careers; in contrast, when their tenure is ending, CEOs have a shorter career time horizon. This causes CEOs in the final years of tenure to prefer explicit incentive combinations to implicit ones ${ }^{3}$. This change in preference is triggered by the CEO's desire to actualize the incentives to make such incentives explicitly more useful for consumption once their tenure ends. In an effort to maximize explicit incentives, CEOs in their final years of service will try again to enhance firm performance by means of earnings management.

In addition to maximizing final compensation payments, CEOs can perform earnings management in their final years of service to improve implicit compensation, such as the odds of holding a post-retirement position ${ }^{3}$. After retirement, CEOs can be appointed as members of the board of commissioners within the same firms, because of their specific expertise, proven during their years of service as CEOs, or can be offered senior positions in other firms. Displaying good performance in their final years of service allows CEOs to enhance the possibility of their being offered well-remunerated post-retirement positions. Taken together, we propose the following hypothesis:

H2: In their final years of service, CEOs will perform income-increasing earnings management

\section{The Effects of Career Origin on CEOs' Earnings-Management Practices in Their Early Years of Service}

Shareholders follow various preferences in choosing CEO candidates, including the opinion that promoting internal CEOs will motivate employees ${ }^{20,21}$. The CEO position is considered to be the "top career achievement" possible and promoting managers from within the organization to be CEOs opens up opportunities for a contest 
among managers. This contest becomes an underlying reason for managers to work harder and achieve success. External CEOs find it more difficult to signal this potential to their staff than internally sourced CEOs.

Moreover, external CEOs expect to stay in their roles for shorter periods than internal CEOs ${ }^{22}$. When managers have a short time horizon, they will be more likely to make decisions that go against shareholders' interests. External CEOs will choose policies that can increase their incentives more rapidly because they expect to stay for a shorter time in the firm. One such policy is to pursue the reporting of positive firm performance, even though they need to use earnings-management practices to achieve this ${ }^{6}$. In this respect, external CEOs do not consider the adverse effects of their opportunistic behaviors on the future of the firm because they think that by then they will have left office.

As a result, with incentives to show shareholders their higher abilities and with shorter career horizons, in their early years of service external CEOs will use higher levels of earnings management compared to newly appointed internal CEOs, and a hypothesis can be formulated as follows:

H3: Earnings-management practices in the early years of external CEOs' service are more prevalent than for internally recruited CEOs.

\section{The Effects of an Affiliate Relationship between CEOs and Shareholders on CEOs' E arnings-Management Practices in Their Early Years of Service}

The existence of ownership concentration in Indonesia can influence the CEO succession process, because one of the few reliable ways for large shareholders to strengthen control over a firm is by appointing key managers ${ }^{23}$. The key managers appointed by shareholders will then be likely to have an affiliate relationship with these shareholders that ensures goal alignment between CEOs and shareholders ${ }^{24,25}$.

CEOs with affiliate relationships with shareholders will prioritize maintenance of good relationships with their affiliates above personal interests during their years of service as $\mathrm{CEOs}^{26}$. This consideration may arise because of a family relationship (to maintain family harmony), a work relationship outside the firm, or share ownership over shareholders. In the light of such relationships, related shareholders are fully aware of the CEO's abilities. It is therefore the case that new CEOs with such affiliations do not have to signal their achievements to shareholders and so their motivation to perform opportunistic earnings-management practices in the early years of service is reduced.

Furthermore, an affiliated CEO appointment can be closely linked to the probability of large shareholders being present within the ownership of a company. Large shareholders are able to create a better monitoring function and can eventually reduce the likelihood that opportunistic actions will be taken by CEOs. In family-owned firms, a CEO is usually a member of the controlling family.

As a result, with CEOs' career concern motivations being smaller when there is an affiliate relationship and with monitoring by large shareholders, a hypothesis can be formulated as follows:

H4: Earnings-management practices in the early years of service of a CEO with an affiliate relationship are less prevalent than for other CEOs.

\section{RESEARCH METHOD}

\section{Data and Sample-Collecting Methods}

The population of this research consists of all share issuers listed in the Indonesia Stock Exchange. Samples are selected based on the following criteria: (1) non-financial company issuers according to the Jakarta Stock Industrial Classification; (2) completeness of required information; and (3) issuers having a period of financial report ending in December. Secondary data related to CEOs and issuer financing are collected from Thomson Reuter's databases, issuers' annual report disclosures, and additional information from various websites, such as Bloomberg.com, Reuters.com, and a variety of other issuer news sites.

\section{Research Models}

The empirical models for this research are based on on previous research models ${ }^{4,6}$. Model 1 is a research model that tests the hypotheses using a discretionary accrual-based earnings-management measurement. Model 2 is a research model used to test hypotheses using a real earnings-management measurement, in which every variable is applicable to firm i for year $t$.

Model 1:

DACC $_{\text {it }}=\alpha_{0}+\alpha_{1}$ Early Years ${ }_{i t}+\alpha_{2}$ Final Year $_{i t}+\alpha_{3}$ External CEO $_{\text {it }}+\alpha_{4}$ Affiliate CEO $_{\text {it }}+\alpha_{\mathrm{i}}$ Control variables $_{\text {it }}+$

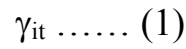

Model 2:

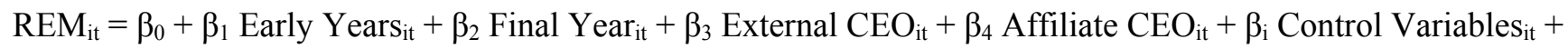

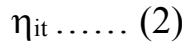




\section{Dependent and Independent Variables}

$\boldsymbol{D A C C}_{i t}$ is an estimated earnings-management level through discretionary accruals model ${ }^{27}$. $\boldsymbol{R E} \boldsymbol{M}_{\text {it }}$ is an estimated earnings-management level indicated by cost of production and discretionary expenses ${ }^{28}$. Both proxies are used because they are "most directly tied to earnings and [that] have unambiguous performance measurement implication" $" 15$.

Early Years it $_{\text {it }}$ an indicator that determines whether a CEO's tenure in year $t$ is early period, as measured by a dummy variable of 1 if the CEO's service years are less than or equal to two and 0 otherwise. A cut-off for early years as half of the median of the CEO's years of service before he/she leaves office ${ }^{4}$. According to the descriptive statistics of 127 CEOs who left office during the period of 2012-2014, the median figure of years of service before leaving office is four years. Final Year $_{i t}$ is an indicator of whether year $t$ is a final year for the CEOs in their position, as measured by a dummy variable of 1 if it is the CEOs' final year and 0 otherwise. External CEO it is an indicator of whether CEOs come from an external career, as measured by a dummy variable of 1 if the CEOs have experience within the firm or through their affiliates for at least two years and 0 otherwise. A cut-off of two years is used in this study because (1) a number of CEO candidates do not immediately take on their CEO positions, but are required to hold another position first ${ }^{6}$ and (2) to provide consistency with previous studies ${ }^{29}$. Affiliate $\boldsymbol{C E}_{\boldsymbol{B}} \boldsymbol{O}_{i t}$ is an indicator of whether the CEOs have an affiliate relationship with the majority shareholders as measured by a dummy variable of 1 if the CEOs have an affiliate relationship with the major shareholders and 0 otherwise. The affiliate relationship in this study refers to a definition given by Law No. 81995 on Capital Markets. The term "shareholders" in this study refers to the majority shareholders.

\section{Control Variables}

The control variables used are based on previous research ${ }^{4,6}$ and have an effect on the earnings-management level. To control for variables affecting earnings-management motivation we include: 1) time-horizon motive (CEO age); 2) political motivation (firm size (total assets)); 3) capital-market motive (firm growth prospect (market-to-book ratio)); firm financing transaction (issue) and analyst coverage (analyst following); 4) level of firm financial distress (leverage); and 5) firm recording loss in previous year (lagged loss). CEO ownership and family ownership are included as controls for alignment incentives that will reduce earnings-management level. We control for firms' performance level (ROA) since movements in accrual-based earnings management is consistent with firm performance ${ }^{30}$. In addition to the control, firm monitoring level, we also include external auditor quality (Auditor).

\section{RESULTS AND DISCUSSIONS}

This study successfully collected data for 1,000 CEO-years representing 426 CEOs from 353 companies. During the analysis period, $127 \mathrm{CEOs}$ resigned. In the observation period, there were 433 non-financial companies listed on the Indonesia Stock Exchange, but only 81.52\% (353) of them provide information on names, dates of employment, and direct CEO ownership. For the accrual-based earnings-management model (Model 1), we obtained a sample of 638 firm years. For the real earnings-management model (Model 2), we obtained a sample of 614 firm years. Table 1 shows the descriptive statistics of the samples for all variables in the model.

\section{Descriptive Analysis of Indonesian CEOs}

It was observed that during the study period of 2012-2014 CEOs had an average tenure of 8.4 years. This is higher than the average CEO tenure, represented by years of service at the time of CEO succession, of 6.2 years. Based on data from the sample we can infer that the distribution of CEOs' years of service and tenure are mostly below 5 years. This signifies that most CEOs hold their positions for less than 5 years and may indicate the average CEO appointment period in Indonesian issuers. The highest frequency of CEOs' years of service/tenure is up to one year. This may suggest that the practice of CEOs holding a temporary position, or being appointed as interim CEOs, is commonplace in Indonesia. In addition, with the high frequency of succession after this one-year period, it is inferred that shareholders can easily replace CEOs for a number of reasons in Indonesia. This may impose a level of pressure on new CEOs to show their expertise to shareholders and to avoid being fired in their early years of service ${ }^{3}$.

In terms of direct ownership, relatively few Indonesian CEOs have direct ownership of the firms they manage. $70.5 \%$ of CEOs from the sample have direct firm ownership. Overall, the average CEO ownership is $1.2 \%$ with a standard deviation of 5.7\%. For the samples, the average CEO ownership in 2012-2014 is $4.00 \%$. In the CEO sample data for 2012-2014, CEOs with an internal career origin dominate, with a total of 235 CEOs, equivalent to $55 \%$. This spread is consistent with a hypothesis suggesting that shareholders prefer internal CEOs to external ones $^{21,22}$. Descriptive statistics of the sample data also suggest that founding CEOs have the highest average of tenure in firms and that the shortest tenure is for external CEOs. Using t-testing it has been statistically proven that 
there is a significant negative difference of 2.24 years in average external CEOs' tenure compared to internal CEOs. This corroborates an argument stating that external CEOs have a shorter career horizon in the firms they manage.

Based on the CEO sample data for 2012-2014, there is no significant difference between the number of CEOs who are in an affiliate relationship with shareholders and the number of those who are not. Both subsamples have approximately the same number, with $49.4 \%$ or 176 CEOs not having an affiliate relationship. This affiliate relationship varies in nature, including CEOs as shareholders, family members of the shareholders, and members of the board of directors or the board of commissioners of the majority shareholders. As for time in office, at the $0.1 \%$ level using t-testing, the two subsamples have a significant difference of 6.76 years. This supports an argument that affiliated CEOs stay focused on maintaining a good relationship with controlling shareholders ${ }^{19}$ and end up holding a longer tenure compared to CEOs with no affiliate relationship. However, this may simply shows a lack of preference for shareholders in appointing CEOs based on their affiliate relationships.

Table.1. Descriptive Statistics

\begin{tabular}{|c|c|c|c|c|}
\hline \multirow{2}{*}{ Variable } & \multicolumn{4}{|c|}{ Descriptive Statistics } \\
\hline & Mean & Std. Dev. & Min & Max \\
\hline$\overline{D A C C_{i t}}$ & -0.001 & 0.085 & -0.233 & 0.296 \\
\hline$R E M_{i t}$ & 0.009 & 0.257 & -0.879 & 0.637 \\
\hline CEO Age $i t$ & 52.263 & 9.082 & 30 & 85 \\
\hline CEO Own.it & 0.011 & 0.057 & 0 & 0.665 \\
\hline Family Own.it & 0.353 & 0.305 & 0 & 0.948 \\
\hline Total Asset & 7.836 & 1.593 & 4.024 & 11.22 \\
\hline$M_{T B}$ & 2.272 & 2.322 & -0.714 & 13.56 \\
\hline$R O A_{i t}$ & 0.060 & 0.101 & -0.262 & 0.456 \\
\hline Leverage $_{i t}$ & 0.241 & 0.186 & 0 & 0.783 \\
\hline LTLeverage $_{i t}$ & 0.167 & 0.188 & 0 & 0.873 \\
\hline Analyst Following it & 3.104 & 5.718 & 0 & 22 \\
\hline Variable & \multicolumn{2}{|c|}{ Value 1} & \multicolumn{2}{|c|}{ Value 0} \\
\hline Early Yearsit & 168 & $26.33 \%$ & 470 & $73.67 \%$ \\
\hline Final Yearit & 81 & $12.70 \%$ & 557 & $87.30 \%$ \\
\hline Ext. CEO it & 99 & $15.52 \%$ & 539 & $84.48 \%$ \\
\hline Aff. CEO it & 309 & $48.43 \%$ & 329 & $51.57 \%$ \\
\hline Issuer $_{i t}$ & 247 & $38.71 \%$ & 391 & $61.29 \%$ \\
\hline Lagged Lossit & 92 & $14.42 \%$ & 546 & $85.58 \%$ \\
\hline Auditor $_{i t}$ & 283 & $44.36 \%$ & 355 & $55.64 \%$ \\
\hline
\end{tabular}

DACC: Accrual earnings management is estimated using Dechow and Dichev model ${ }^{31}$ with development of McNichols ${ }^{27}$; Early Years: The indicator if CEO's tenure is less than or equal to 2 years; Final Year: The indicator if year t+1 early years worth 1; External CEO: The indicator if the previous year CEO worked outside the company; Affiliate CEO: The indicator if CEO has affiliate relationship with shareholders; CEO Age: CEO's age in year t; CEO Ownership: CEO's ownership in year t; Family Ownership: Family ownership at first level according to definition by Arifin (2003); Total Asset: Natural logarithm of total assets in year t-1. Market-to-Book Ratio: The ratio of capitalization in market to equity in year t-1; ROA: The ratio of net income to total assets in year t; Leverage: The ratio of total debt to total assets in year t-1; Lagged Loss: The indicator if reporting loss in year t-1; Issuer: The indicator if in the relevant year an IPO occurred, or an increase of $>10 \%$ of outstanding shares, or an increase $>20 \%$ of long-term debt in year $\mathrm{t}$; Auditor: The indicator if audited by accounting firm which is affiliated to the Big Four Group in year $t$.

\section{CEO Earnings Management in Their Early and Final Years of Service}

Table 2 presents estimated results of Hypotheses 1 and 2 using two earnings-management measurements. The results show that the variable Early Years has a positive significant coefficient, both for accrual-based and real earnings management. This result supports Hypothesis 1 that CEOs perform income-increasing earnings management in their early service years. The variable Final Year has a positive significant coefficient for the real earnings-management model, but not for the accrual-based earnings-management model. This result supports Hypothesis 2 that states CEOs perform income-increasing earnings management in their final service years.

An insignificant estimated result for the accrual-based earnings-management models is likely to be caused by the effect of income-decreasing accrual-based earnings-management practices within the years of CEO succession $^{7,17}$. This study suggests that the effects of earning bath new CEOs carry out in the year of succession cause this variable to have a negative, albeit insignificant, value. This can occur due to a measurement of the variable Final Year that is focused on the final year of a CEO's service, so that it may be affected by earning bath earnings-management practices that new CEOs carry out. 
Table.2. Regression Results on Earnings Management by CEO in Their Early and Final Years of Service

\begin{tabular}{|c|c|c|}
\hline Variables & Var. Dep.: DAC $C_{i t}$ & Var. Dep.: REMit \\
\hline Early Yearsit & $0.0091 *$ & $0.0571 * * *$ \\
\hline Final Year ${ }_{i t}$ & 0.0023 & $0.0348 * * *$ \\
\hline External CEO & -0.0208 & $-0.1047 * * *$ \\
\hline Affiliate CEOit & -0.0031 & -0.0359 \\
\hline CEO Age $e_{i t}$ & $0.0012 * *$ & $0.0023 * *$ \\
\hline CEO Ownershipit & $-0.4883 * * *$ & $-1.4423 * * *$ \\
\hline Family Ownership $_{\text {it }}$ & $-0.0397 *$ & -0.0308 \\
\hline Total Asset ${ }_{i t}$ & $0.0195 * * *$ & $0.0238^{*}$ \\
\hline MTB Ratio $_{\text {it }}$ & 0.0017 & $0.0073 * * *$ \\
\hline$R O A_{i t}$ & $0.6055 * * *$ & $-0.3761 * * *$ \\
\hline Leverage $_{i t}$ & -0.0271 & \\
\hline Lagged Lossit & $0.0177 * *$ & \\
\hline Issuer $_{i t}$ & -0.0045 & \\
\hline Auditor $_{i t}$ & 0.006 & \\
\hline LTLeverage $_{i t}$ & & -0.0455 \\
\hline Analyst Following it & & 0.0024 \\
\hline Constant & $-0.3686 * * *$ & $-0.4026^{* *}$ \\
\hline $\mathrm{N}$ & 638 & 614 \\
\hline Prob (Wald-stat) $\mid \mathrm{R}^{2}$ & $0.0000 \mid 0.3712$ & $0.0000 \mid 0.1380$ \\
\hline
\end{tabular}

\section{Earnings Management Conducted by External CEOs and Affiliated CEOs in Their Early Years of Service}

Table 3 presents regression results for testing Hypotheses 3 and 4 using two earnings-management measurements. The results indicate that interactions between the variables Early Years and External CEO are not significant, either in the accrual-based or the real earnings-management models. This result suggests that CEOs' career origin has no effect on earnings-management practices in the early years of service.

Table.3. Regression Results on Earnings Management by External and Affiliate CEO

\begin{tabular}{|c|c|c|}
\hline Independen Variables & Var. Dep.: $D A C C_{i t}$ & Var. Dep.: $R E M_{\text {it }}$ \\
\hline \multicolumn{3}{|l|}{ Panel B: External CEO (H3) } \\
\hline Early Yearsit & 0.0088 & $0.0635 * * *$ \\
\hline Final Year $_{i t}$ & 0.0022 & $0.0339 * * *$ \\
\hline External $C E O_{i t}$ & -0.0218 & -0.0864 \\
\hline $\begin{array}{l}\text { Early Yearsit } \boldsymbol{X} \text { External CEO } \boldsymbol{O}_{\text {it }} \\
\text { Control Variables**** }\end{array}$ & 0.0027 & -0.0229 \\
\hline $\mathrm{N}$ & 638 & 614 \\
\hline Prob (Wald-stat) $\mid R^{2}$ & $0.0000 \mid 0.3712$ & $0.0000 \mid 0.1367$ \\
\hline \multicolumn{3}{|l|}{ Panel B: Affiliate CEO (H4) } \\
\hline Early Yearsit & $0.015 * *$ & $0.0609 * * *$ \\
\hline Final Year $_{i t}$ & 0.0033 & $0.0359 * * *$ \\
\hline Affiliate $C E O_{i t}$ & 0.0064 & -0.0262 \\
\hline $\begin{array}{l}\text { Early Yearsit } x \text { Affiliate } \text { CEO }_{\text {it }} \\
\text { Control Variables**** }\end{array}$ & -0.0144 & 0.0081 \\
\hline $\mathrm{N}$ & 638 & 614 \\
\hline Prob (Wald-stat) $\mid R^{2}$ & $0.0000 \mid 0.3711$ & $0.0000 \mid 0.1242$ \\
\hline
\end{tabular}

Such a result is inconsistent with the prediction resulting from there being various reasons for shareholders to appoint external CEOs. These various reasons lead to various types of external CEOs; in the same manner, external CEOs are appointed based on the firm's needs. For example, external CEOs appointed by shareholders can be those with the special expertise needed for restructuring, or they can be interim CEOs. These two types of CEOs do not think of their career as an important element since, by design, they do not think they will stay in office for a long period of time 6 . The career origin measurement used in this study does not specifically consider this point, and this may produce an estimation that is inconsistent with prior predictions.

Estimated results of the models indicate that interactions between the variables Early Years and Affiliate CEO have insignificant coefficients, both in the accrual-based and the real earnings-management models. This result shows that an affiliate relationship between CEOs and shareholders does not affect earnings-management practices in the early years of CEOs' service. 


\section{Additional Test Result}

We performed additional testing by replacing Early Years and Final Year variables with the CEO tenure variable. The measurement of CEOs' tenure uses the variable Tenure that is a natural logarithm of CEOs' service years. The result shows that the variable CEO tenure has a significant negative coefficient for real earningsmanagement practices, but it has an insignificant coefficient for accrual-based earnings-management practices. The direction of the coefficient also matches a prediction suggesting that CEOs perform aggressive earnings in their early years of service, and that this practice declines throughout their tenure. Differences in results between real and accrual-based earnings-management models indicate CEO influence on the two types of policies and corroborate the argument of this study. Accrual-based earnings-management models indicate CEO influence on the two types of policies and corroborate the arguments of this study.

\section{CONCLUSION}

This study aims to determine the effects of CEOs' career concerns on accrual-based and real earnings management conducted by firms. This study finds consistent evidence indicating that CEOs conduct real incomeincreasing earnings management in their early and final years of service. On the other hand, there is marginal evidence of accrual-based earnings management in the early years of a CEO's service. This result implies that to achieve earnings management CEOs' prefer to manage firms' operational policies in preference to accounting policies or accounting estimations. However, this study cannot confirm that accrual-based and real earningsmanagement practices vary because of CEOs' career origins and/or affiliate relationships with shareholders.

The study is subject to several caveats. First, this research uses only a few CEOs characteristics. Future research may be able to investigate other characteristics expected to influence CEOs' career concerns and managerial labor markets, such as CEO reputation (e.g. CEO "superstars") ${ }^{32,33}$ and the level of CEOs' self-confidence ${ }^{34}$. Second, affiliate relationship focuses on CEOs' affiliate relationships with shareholders; this restricted definition reflects information limits in disclosures by issuers in revealing information to the general public. Future research may wish to study CEOs' family relationships within family firms, as suggested by Yang ${ }^{33}$. Third, this study's examination of a three-year period causes the number of CEO successions to be limited in terms of properly describing a CEO's years of tenure in office. Future research may use a longer period of, perhaps, more than ten years.

\section{REFERENCES}

[1] DR Dalton, IF Kesner. Organizational performance as an antecedent of inside/outside chief executive succession: An empirical assessment. Academy of Management Journal, 28 (1985) 749-762.

[2] EF Fama. Agency problems and the theory of the firm. The Journal of Political Economy, 88 (1980) 288-307.

[3] R Gibbons, KJ Murphy. Optimal incentive contracts in the presence of career concerns: Theory and evidence. Journal of Political Economy, 100 (1992) 468-505.

[4] A Ali, W Zhang. CEO tenure and earning management. Journal of Accounting and Economics, 59 (2015) 60-79.

[5] PM Dechow, W Ge, C Schrand. Understanding earnings quality: A review of the proxies, their determinants and their consequences. Journal of Accounting and Economics, 50 (2010) 344-401.

[6] YF Kuang, B Qin, JL Wielhouwer. CEO origin and accrual-based earnings management. Accounting Horizons, 28 (2014) 605-626.

[7] P Adiasih, IW Kusuma. Manajemen laba pada saat pergantiaan CEO (Dirut) di Indonesia. Jurnal Akuntansi dan Keuangan, 13(2) (2011) 67-69.

[8] GW Yasa, Y Novialy. Indikasi manajemen laba oleh chief executive officer (CEO) baru pada perusahaan-perusahaan yang terdaftar di pasar modal Indonesia. Jurnal Akuntansi dan Bisnis, 7(1) (2012) 40-56.

[9] NPMD Sadia, IM Sukartha. Pengaruh pergantian CEO pada praktik manajemen laba perusahaan publik yang terdaftar di bursa efek Indonesia. EJournal Akuntansi, 8(1) (2014) 200-210.

[10] B Holmström. Moral hazard in teams. The Bell Journal of Economics, 13 (1982) 324-340.

[11] JD McGinnis, JA Miles, SM Chu, TL Campbell. Executive compensation and the horizon problem: A synthesis of the economics of age and decision management. Managerial Finance, 25 (1999) 34-49.

[12] PM Healy. The effect of bonus schemes on accounting decisions. Journal of Accounting and Economics, 7 (1985) 85-107.

[13] DS Dhaliwal, GL Salamon, D Smith. The effect of owner versus management control on the choice of accounting methods. Journal of Accounting and Economics, 4(1) (1982) 41-53.

[14] Q Cheng, TD Warfield. Equity incentives and earnings management. The Accounting Review, 80 (2005) 441-476.

[15] E Demers, C Wang. The Impact of CEO Career Concerns on Accruals Based and Real Earnings Management. Working Paper, INSEAD and Naval Postgraduate School (2010).

[16] P Wells. Earnings management surrounding CEO changes. Accounting and Finance, 42 (2002) 169-193.

[17] AL Reitangga, MG Tearney. Mandatory CEO retirements, discretionary accruals, and corporate governance mechanism. Journal of Accounting, Auditing, and Finance, 18(2) (2003) 255-280.

[18] N Hu, Q Hao, L Liu, LJ Yao. Managerial tenure and earnings management. International Journal of Accounting \& Information Management, 23(1) (2015) 42-59.

[19] ML Yang. The impact of controlling families and family CEOs on earnings management. Family Business Review, 23(3) (2010) 266279.

[20] W Chan. External recruitment versus internal promotion. Journal of Labor Economics, 14(4) (1996) 555-570. 
[21] A Agrawal, CR Knoeber, T Tsoulouhas. Are outsiders handicapped in CEO successions?. Journal of Corporate Finance, 12 (2006) 619-644.

[22] GF Brady, RM Fulmer, DL Helmich. Planning executive succession: The effect of recruitment source and organizational problems on anticipated tenure. Strategic Management Journal, 3(3) (1982) 269-275.

[23] S Claessens, S Djankov, LHP Lang. The separation of ownership and control in East Asian corporations. Journal of Financial Economics, 58 (2000) 81-112.

[24] M Burkart, F Panunzi, A Shleifer. Family firms. The Journal of Finance, 58(5) (2003) 1167-2201.

[25] A Ali, TY Chen, S Radhakrishnan. Corporate disclosures by family firms. Journal of Accounting and Economics, 44 (2007) $238-286$.

[26] A Prencipe, G Markarian, L Pozza. Earnings management in family firms: Evidence from R\&D cost capitalization in Italy. Family Business Review, 21 (2008) 71-88.

[27] MF McNichols. The quality of accruals and earnings: The role of accrual estimation errors: Discussion. The Accounting Review, 77 (2002) 61-69.

[28] S Roychowdhury. Earnings management through real activities manipulation. Journal of Accounting and Economics, 42 (2006) 335370.

[29] Y Zhang, N Rajagopalan. Explaining new CEO origin: Firm versus industry antecedents. Academy of Management Journal, 46 (2003) 327-338.

[30] PM Dechow, RG Sloan, AP Sweeney. Detecting earnings management. The Accounting Review, 70(2) (1995) 193-225.

[31] PM Dechow, ID Dichev. The quality of accruals and earnings: The role of accrual estimation errors. The Accounting Review, 77(Supplement) (2002) 35-59.

[32] J Francis, AH Huang, S Rajgopal, AY Zang. CEO reputation and earnings quality. Contemporary Accounting Research, 25 (2008) $109-114$.

[33] R Khurana. Finding the right CEO: Why boards often make poor choices. MIT Sloan Management Review, Fall 2001 (2001).

[34] CM Schrand, SLC Zechman. Executive overconfidence and the slippery slope to financial misreporting. Journal of Accounting and Economics, 53(1) (2012) 311-329. 